\title{
A CONSTRUÇÃO DISCURSIVA DE ESTEREÓTIPOS FEMININOS ENCONTRADOS NOS CONTOS DA REVISTA JORNAL DAS MOÇAS DA DÉCADA DE 50
}

\author{
$\underline{\text { Lailla Batista Soares }{ }^{1} \text {; Palmira Virgínia Bahia Heine Alvarez }}$ \\ 1. Bolsista PIBIC/CNPq, Graduando em Letras Vernáculas, Universidade Estadual de Feira de Santana, e-mail: \\ laillagarota@hotmail.com \\ 2. Orientador, Departamento de Letras e Artes, Universidade Estadual de Feira de Santana, e-mail: \\ pavibheine@gmail.com
}

PALAVRAS-CHAVE: estereótipo, jornal das moças, mulher

\section{INTRODUÇÃO}

A análise do discurso nasce como uma disciplina que não se preocupa em observar apenas elementos formais do texto, mas preocupa-se com a produção dos sentidos, ou seja, pensando onde, como e por que esses sentidos são gerados. Surgiu na década de 60 como uma reação às concepções de língua vigentes na época, opondo-se à noção puramente formal que vigorava nos estudos lingüísticos e reivindicando um lugar para o estudo do sujeito e do sentido.

Segundo Orlandi (2005) "o discurso é o efeito de sentido entre interlocutores". Pensando assim, a análise do discurso trabalha com esses sentidos que são gerados a partir de sujeitos que ocupam posições sociais, porém nunca de forma direta e linear, mas perpassando pela ideologia que interpela os sujeitos e entrando em contato com o contexto sócio-histórico em que se encontra inserido esse discurso.

A década de 50 foi um período pelo qual o país passou por um grande desenvolvimento industrial o que atraiu diversos profissionais para diferentes setores de trabalho nas indústrias. Além disso, o consumismo passou a ser incentivado, houve uma expansão da classe média e o nível de escolaridade feminina sofreu um aumento, no entanto, apesar do avanço no grau de escolaridade da sociedade, as concepções de que a mulher deveria se dedicar exclusivamente ao lar, ao marido e aos filhos ainda estavam impregnadas na consciência social.

As revistas que circulavam na década de 50, principalmente as voltadas ao público feminino, refletiam em suas publicações os traços contextuais históricos desse período, assim como o imaginário social da época, no que diz respeito à forma de se portar e viver em conjunto dentro dessa década.

Dentre essas revistas veiculadas nesse tempo, existia uma revista intitulada Jornal das Moças, objeto de estudo desse trabalho, um periódico produzido no Rio de Janeiro e que viajava o país inteiro, tendo como público principal as mulheres de classe média, porém circulava não só entre o público feminino, como também poderia ser acessada pelos homens e acabava servindo como um "manual" de como ser mulher e de como tratar uma mulher em meados dos anos 50, separando-as das outras mulheres que fugiam às normas e acabavam sendo taxadas de levianas ou até mesmo prostitutas.

Essa caracterização feminina através de regras criadas socialmente também estava presente numa seção onde eram veiculados contos e novelas, na qual, diariamente, publicava-se um capítulo de cada conto ou novela, até a finalização da trama. Esses 
contos eram utilizados para educar as moças e mulheres sobre o "correto" comportamento que deveriam ter no namoro e casamento e no comportamento social em festas e espaços públicos.

Assim, pensando no discurso como elemento no qual se pode observar o funcionamento da ideologia a respeito da construção discursiva sobre a mulher, esse trabalho tem como objetivo analisar a seção de contos e novelas presente nessa revista, nas edições da década de 50, trazendo recortes que venham a mostrar como os discursos sobre a feminilidade influenciaram toda aquela sociedade nas suas formas de tratar a mulher, de saber o limite entre os gêneros, entre o feminino e masculino, traçando um lugar marcado para as mulheres dentro do que se acreditava ser o ideal, além de contribuir para a construção do que se considera "ser mulher" atualmente.

\section{MATERIAL E MÉTODOS OU METODOLOGIA (ou equivalente)}

Este trabalho foi realizado a partir da análise de contos publicados em onze exemplares da revista Jornal das Moças, de Janeiro a Março do ano de 1950. Foram selecionados cinco contos e novelas. Partindo desta seleção, foram analisados conceitos como formação discursiva, interdiscurso, formação ideológica dentre outros. Também foram analisadas as marcas discursivas e ideológicas encontradas nos recortes de textos selecionados que dizem respeito ao que se entendia ser mulher na década de 50.

\section{RESULTADOS E/OU DISCUSSÃO (ou Análise e discussão dos resultados)}

As análises dos contos e novelas, na Revista Jornal das Moças, baseadas nas teorias da análise do discurso de linha francesa, nos permitiu adentrar o universo discursivo da revista e contribuir com os estudos a respeito da feminilidade, levando em consideração os sentidos que são produzidos a partir do funcionamento da ideologia. Para realizar a análise, foram selecionadas diversas materialidades como contos e novelas cuja temática girava em torno da noção de feminilidade e do que era ser uma mulher dentro da sociedade dos anos 50, como por exemplo: "A dúvida" (02.02.1950); Sombras Fugazes (05.01.1950); "Uma carta de amor" (12.01.1950); "Casamento por dever" (26.01.1950) e “A herdeira” (09.03.1950).

\section{CONSIDERAÇÕES FINAIS (ou Conclusão)}

Os contos que foram selecionados têm em comum a presença de um interdiscurso que diz que a mulher só é mulher se encontrar um homem, se casar, ter filhos e se dedicar a família. Todos eles mostram, de alguma forma, que a mulher que não casa não é feliz, pois sua meta de vida deve ser o casamento.

O estudo da constituição do que era considerado "ser mulher" na sociedade da década de 50, nos permite perceber de que modo a ideologia funciona em relação ao que se entendia ser mulher naquela época e se ressignifica na atualidade, trazendo consigo uma gama de estereótipos já construídos que apresentam o que se entende sobre a mulher também na sociedade atual. Dessa forma, o objetivo principal desse trabalho foi analisar 
discursivamente, com base na Análise do Discurso de Linha Francesa, os discursos que constroem a imagem feminina e os modos de construção discursiva da feminilidade a partir de contos e novelas na Revista Jornal das Moças da década de 50.

\section{REFERÊNCIAS}

ORLANDI, Eni Puccinelli. Análise de Discurso: princípios e procedimentos. 8; ed. Campinas: Pontes, 2009.

HEINE, Palmira. Tramas e Temas em Análise do Discurso. 1.ed. Curitiba, PR: CRV, 2012.

PINSKY, Carla Bassanezi. Mulheres dos anos dourados. São Paulo: Contexto, 2014. 